\title{
Optimization of Metallurgical Reactors Using Mathematical and Physical Modeling
}

\author{
LIFENG ZHANG ${ }^{1,2}$ \\ 1.-School of Metallurgical and Ecological Engineering, University of Science and Technology \\ Beijing, Beijing 100083, China. 2.—e-mail: zhanglifeng@ustb.edu.cn
}

\section{OPTIMIZATION OF METALLURGICAL REACTORS USING MODELING}

Because of the tremendous cost of pilot-plantscale metal industrial trials, previous attempts to develop new metallurgical processes have generally relied on scaling up small bench-scale experiments. Because of the lack of true understanding of the rate constants, mixing phenomena, and geometric effects that control the success of the real process, many previous pilot-plant operations have been unsuccessful. Water modeling and mathematical modeling instead have become the main approaches to optimize the metallurgical reactors. To achieve success, the model must accurately predict the phenomena of true interest, including the following:

- Multiphase and turbulent fluid flow within each vessel in the process, incorporating the effects of gas stirring and including transient variations, which are the main source of variability in the product

- Mixing phenomena in each vessel, including solidification, heating, and remelting of a metal layer around alloy particle additions, which directly controls the success of alloying, and is important to other reactions as well

- Heat-transfer phenomena, including temperature drops between each vessel

- Evolution of composition during each vessel, including the thermodynamics and kinetics of the reactions between the molten metal and interfaces with the top slag and bubble surfaces, coupled with fluid flow and mixing phenomena

- Effects of the true three-dimensional features of the vessel shape (including location of inlet and outlet launder), gas injection location and flow

Lifeng Zhang is the guest editor for the Process Technology \& Modeling Committee of the TMS Extracttion \& Processing Division, and coordinator of the topic Optimization of metallurgical Reactors: Mathematical and Physical Modeling in this issue. rates, and other operating conditions on the above phenomena

Extensive past work has employed physical water models to successfully investigate fluid flow phenomena in metallurgical processes such as the steel refining and casting process ${ }^{1-5}$ and the aluminum remelting process. ${ }^{6-10}$ The first water modeling for the fluid flow in a continuous casting mold study was carried out by Afanas'Eva et al. ${ }^{11}$ for a straight bore nozzle system. Physical water models can model single-phase fluid flow because of the simulation of kinematic viscosity of steel and water. However, it is hard to use water modeling to simulate the solidification of molten metals.

With the tremendous increases in the power of computer hardware and modeling software, computational modeling offers a better design tool for creating new processes. Numerical simulation has the potential to quantify the phenomena taking place in a commercial-scale process before it is constructed. Mathematical models can yield added insight into flow phenomena. Computational models based on finite-volume or finite-element solution of the Navier-Stokes equations can include phenomena such as heat transfer, multiphase flow, and solidification in steel casting without the inaccuracies inherent in a water model. Extensive research focused on the design of the metallurgical reactors using mathematical modeling such as for molten steel system $^{2,12-22}$ and molten aluminum system. ${ }^{6,23}$

\section{THE CURRENT JOM TOPIC}

The current JOM topic addresses the optimization of metallurgical reactors, such as smelting, refining, and casting furnaces for steel and aluminum, using mathematical and physical modeling to simulate the fluid flow, heat transfer, mass transfer, and solidification. Thirteen papers were collected for this topic. Li et al. ${ }^{24}$ studied electroslag remelting of a die steel ingot using mathematical modeling. Meng et al. $^{25}$ calculated the macrosegregation in a 
water-cooled flat ingot. Zhang et al. ${ }^{26}$ simulated the solidification of $\mathrm{Fe}-\mathrm{Ni}$-based ingot under a vacuum condition. Liu et al. ${ }^{27}$ studied the transient flow and inclusion motion in a continuous-casting mold using large eddy simulation. Zhang et al. ${ }^{28}$ studied characteristics of the fluid flows in a self-stirring reactor using both physical and mathematical modeling. Liu et al. ${ }^{29}$ also applied both physical and mathematical models for the aluminum reduction cell. $\mathrm{Li}$ et al. ${ }^{30}$ numerically simulated the mixing process of alumina with a multicomponent flow model coupled electromagnetic forces in aluminum reduction cells. Zhao et al. ${ }^{31}$ calculated the multiphase flow in a mechanically agitated tank. Zhang and $\mathrm{Li}^{32}$ investigated the fluid flow and mixing phenomena in an $\mathrm{RH}$ degasser using water modeling. Guo et al. ${ }^{33}$ optimized the burner nozzles in a hot blast stove using mathematical modeling. Wang et al. ${ }^{34}$ numerically simulated the thermal process in $\mathrm{W}$ shape radiant tube burners. Wu et al. ${ }^{35}$ performed three-dimensional numerical analysis on the effect of the gas distribution on the characteristics inside a COREX shaft furnace. Chen et al. ${ }^{36}$ studied the tuning of the planar-flow melt-spinning process.

\section{REFERENCES}

1. Y. Chen, L. Zhang, S. Yang, and J. Li, JOM 64, 1080 (2012).

2. L. Zhang, S. Yang, K. Cai, J. Li, X. Wan, and B.G. Thomas, Metall. Mater. Trans. B 38B, 63 (2007).

3. L. Zhang and S. Taniguchi, Ironmak. Steelmak. 29, 326 (2002).

4. D. Sheng, C. Kim, J. Yoon, and T. Hsiao, ISIJ Int. 38, 843 (1998).

5. J.W. Hlinka, Mathematical Process Models in Iron-Steel Making (London, UK: The Metals Society, 1975), pp. 157164.

6. Y. Wang and L. Zhang, Metall. Mater. Trans. B 42B, 1051 (2011).

7. Y. Wang and L. Zhang, Light Metals 2009, ed. G. Bearne (Warrendale, PA: TMS, 2009), pp. 581-586.

8. L.I. Kiss, S. Poncsák, and J. Antille, Light Metals 2005, ed. H. Kvande (Warrendale, PA: TMS, 2005), pp. 559-564.

9. J. Zoric and A. Solhem, J. Appl. Electrochem. 30, 787 (2000).

10. S. Fortin, M. Gerhardt, and A.J. Gesing, Light Metals 1984, ed. J.P. McGeer (Warrendale, PA: TMS, 1984), pp. 721-741.
11. K.I. Afanas'Eva and G.P. Iventsov, Stal 18, 599 (1958).

12. E.A. Mizikar, Trans. TMS-AIME 239, 1747 (1967).

13. R.K. Iyengar and W.O. Philbrook, Metall. Trans. 3, 1823 (1972).

14. J. Lait, J.K. Brimacombe, and F. Weinberg, Ironmak. Steelmak. 2, 90 (1974).

15. M. Uehara, I.V. Samarasekera, and J.K. Brimacombe, Ironmak. Steelmak. 13, 138 (1986).

16. W.R. Storkman, (Master's Thesis, University of Illinois, 1990).

17. S.K. Choudhary and D. Mazumdar, Steel Res. 66, 199 (1995).

18. R.D. Morales, S. Lopez-Ramirez, J. Palafox-Ramos, and D. Zacharias, Ironmak. Steelmak. 28, 33 (2001).

19. H. Lei, K. Nakajima, and J.-C. He, ISIJ Int. 50, 1735 (2010).

20. Y. Li, L. Zhang, and Y. Ren, Celebrating the Megascale: Proceedings of the Extraction and Processing Division Symposium on Pyrometallurgy in Honor of David G.C. Robertson, ed. P.J. Mackey, E.J. Grinsey, R.T. Jones, and G. A. Brooks (Warrendale, PA: TMS, 2014), pp. 659-666.

21. Y. Wang and L. Zhang, ISIJ Int. 50, 1783 (2010).

22. Y. Wang and L. Zhang, Metall. Mater. Trans. B 42B, 1319 (2011).

23. M.A. Dohem, A.M. EL-Kersh, and M.M. Ali, Metall. Mater. Trans. B. 38, 113 (2007).

24. B. Li, Q. Wang, F. Wang, and M. Chen, JOM 66 (2014). doi:10.1007/s11837-014-0979-y.

25. Q. Meng, F. Wang, C. Li, M. Li, J. Zhang, and G. Cui, JOM 66 (2014). doi:10.1007/s11837-014-1003-2.

26. L. Zhang, C. Gao, C. Li, and J. Peng, JOM 66 (2014). doi:10. 1007/s11837-014-1017-9.

27. Z. Liu, L. Li, B. Li, and M. Jiang, JOM 66 (2014). doi:10. 1007/s11837-014-1010-3.

28. Z. Zhang, Q. Zhao, C. Lv, Z. Dou, G. Lv, D. Zhang, and T. Zhang, JOM 66 (2014). doi:10.1007/s11837-014-1015-y.

29. L. Yan, L. Yudong, Z. Ting'an, and F. Naixiang, JOM 66 (2014). doi:10.1007/s11837-014-0981-4.

30. H. Zhang, S. Yang, H. Zhang, J. Li, and Y. Xu, JOM 66 (2014). doi:10.1007/s11837-014-1020-1.

31. H-L. Zhao, Y. Liu, T-A. Zhang, S. Gu, and C. Zhang, JOM 66 (2014). doi:10.1007/s11837-014-1012-1.

32. L. Zhang and F. Li, JOM 66 (2014). doi:10.1007/s11837-0141023-y.

33. H. Guo, B. Yan, J. Zhang, F. Liu, X. Li, and Y. Pei, JOM 66 (2014). doi:10.1007/s11837-014-1022-z.

34. Y. Wang, J. Li, L. Zhang, H. Ling, and Y. Li, JOM 66 (2014). doi:10.1007/s11837-014-1021-0.

35. S. Wu, K. Du, J. Xu, W. Shen, M. Kou, and Z. Zhang, JOM 66 (2014). doi:10.1007/s11837-014-1019-7.

36. Y-G. Su, F. Chen, C-M. Chang, C-Y. Wu, M-H. Chang, and C.A. Chung, JOM 66 (2014). doi:10.1007/s11837-014-0982-3. 